\title{
Image and Accusations
}

\author{
Santoso, J, H. \\ English for Creative Industry, Faculty of Letters, Petra Christian University, Siwalankerto 121 - 131, \\ Surabaya 60236, East Java, INDONESIA \\ Emails:m11414003@petra.ac.id
}

\begin{abstract}
Hoax news became more apparent in the recent time in Indonesia. This creative work would like to find out how the hoax destroys life and the struggle to restore. Later, I would like to show how the relationship, integrity and reputation destroyed by hoax and how the track records used to restore the reputation. The creative work follows a story of a victim of a slander whose life was destroyed by it and would like to repair his image back. He had to investigate the culprit behind the slander. He found out that the culprit was his own friend. He confronted the culprit to stop the slander once and for all. The held a press conference with the help of his friends to restore his reputation. This story is represented through realistic novel as this genre would create a sense of realism that the readers could relate to.
\end{abstract}

Keywords: Hoax News, Image, Reputation, Press Conference, Testimony

\section{INTRODUCTION}

As soon as it is time for me to work on my final project, I have taken interest into one of the social issues that are recently became quite a phenomenon in Indonesia. The social issue that I mention here is about hoax news in social media. The meaning of hoax news, according to Law of Information and Technology (UU ITE) verse 28, article 1, is a news or information that are misleading created by a particular person without a proper authorization (Arti Berita Bohong dan Menyesatkan dalam UU ITE, 2012). There are two stories about victims of hoax news that inspire me. One of the two stories is about Taufik Widodo, the victim of hoax news about his meatball that contains pork meat, which resulted to his business failing (Djamhari, 2017). The second story is about hoax news of Jokowi's involvement in Indonesian Communist Party (PKI). Jokowi felt enraged over the hoax news and said that he will beat the person who spread the hoax news (Lismartini \& Mukti, 2018). Because of those two stories, I was inspired to make my own story about a victim of hoax news. The victim's social life was ruined because the society casts a negative attitude towards the victim. What fascinates me the most is the effort of a victim of hoax news in restoring his or her image. I found that restoring a damaged image or reputation requires a great deal of effort in convincing the society and preparing the necessary data. In addition, there are not many news that shows the procedure on how a victim of hoax news restore his or her image.

Through the creative work, I would like to highlight the effort of victim of hoax news in restoring his or her image. Image is an impression towards a person, a group of people or an organization to the public (Image, n.d.). Hoax news damages a person's image in the society. One particular effect are questioning attitude from the people. An example of this particular effect is about Melinda, the singer of "Cinta Satu Malam". According to the hoax news, Melinda was reported working as a prostitute on Hotel Alexis. From the hoax news, many of Melinda's fan start to question her credibility and moral as an artist (Purnomo, 2017). At this point, the victim's image is damaged by the hoax news. The life of the victim would also change due to how the society around the victim view or react to the hoax news. In addition, the victim would have to restore his or her image by giving clarification that the news is indeed false. For example, Taufik, the owner of meatball stall, tries to prove that his meatball does not contain pork meat. He even shows that the symbol he got from Indonesian Ulema Council (MUI) is real and cannot be replicated (Djamhari, 2017). There are few news that shows the evidence that the victim uses in restoring his or her image. It should be noted that not everyone would believe to the clarification given by the victim in an instant. The focus that I want to take is the solutions and evidence that the victim would choose 
to state his or her defense. In addition, I also want to focus on the difficulties that the victim would experience such as being treated badly by the society who believe to the news.

I choose fictional novel as a form because it allows me to explore the struggle of a victim of hoax news. According to Britannica Encyclopedia, novel is a narrative prose with a considerable length and plot complexity that deals imagination through human's experience through a sequence of events on the plot involve a person or a group of people in a particular setting in the story ("Novels", 1999). Novel allows me to show the victim's character development from his or her struggle throughout the story. In addition, novel allows me to show the steps that the victims can do to overcome the hoax news. Unlike other kinds of form such as play script, I can show the details of the proof that a victim show in the story. Character's feelings and thoughts can also be described inside the novel through the description, whether the character is in despair, troubled and other feelings and thoughts that could happen in the story.

The genre that I would like to use for my creative work is a subgenre of fiction, which is realistic fiction. Realistic fiction is a story written about events that did not actually happen but could happen in real life. The people, events and places that are presented in the story may also be real (Goodreads, n.d.). The events of being a victim of hoax news are a real events that happened several times in Indonesia. In my story, the events that happened is real and can be inspired by the real event. Characters that will appear in my story will be fictional but credible as if those characters could exist in real life. I want to make a story in which readers can see how a victim take the solutions to overcome hoax news realistically in real life. In addition, I also want to show how hoax news could damage the victim's image in the eyes of the society and also the victim's life such as being completely ignored or even casted away by the society.

From the project that I want to make, I want to explore the victim's struggle in restoring his or her image and the effect of hoax news to the victim's image or reputation: How the hoax destroys Boedi's life and how Boedi struggles to restore his image or reputation after the hoax.

From this project, I want to show answers and give possible solutions to the questions that I have stated in the previous point: The hoax destroys Boedi's current and future career, his reputation as a responsible employee and relationship with the family and Boedi will use his past reputation and his good track records to restore his damaged reputation.

Next, I will discuss and explain the two theories that I will use in making the creative work for the project and answering my statement of the study. The first that I would like to use is Online Slander by Steven Wyer. The second theory that I would like to use is Image Restoration theory, or also referred as Image Repair theory by William L Benoit.

Based on the book Violated Online, Steven Wyer describes how rumor and slander on the Internet and social media can be very dangerous in damaging a reputation. Steven Wyer is the current Managing Director of Reputation Advocate based on Tennessee. On his book, Wyer describes what sources the slander can appear from, how it will turn into and explain how to either avoid the slander or repair the damaged reputation depending on the situation. Wyer divides different sources of slanders such as out of out of nowhere, transparency, own name, first click, family and friends, little things, comment sections, conviction, immediate and complaints. For my story, I will use family, friends and employees and little things to explain how hoax or slander can destroy Boedi's aspects of life such as his future career, his reputation as a responsible employee and relationship with the family. In addition I will use some parts of out of nowhere since in a certain sense the meaning answers my questions and does conform with my story.

First, Wyer explains the background that internet and social media grows exponentially in the recent years. He explains the growth of social media from its humble beginnings into one that we know today. However, the focus that I want to take in this particular part is that slander can come from anywhere at anytime. Information that once are personal can now be accessed through single click. Wyer (2012) listed several information such as mail address, phone numbers, travel calendar, even security number are available for everyone to see (pg. 20).

Second, Wyer (2012) believes that the one who can damage the reputation the most is the closest friends, family or employees (p.51). This is possible because they, the close friends and family, have access and can take all and any kind of information that the victim have and turn them against the victim should the relationship turn sour. Once the negative content was posted on the social media or internet, there is no way to remove such content. The damage, which applies to not 
only the victim but also to the attacker as well, can be in range of frustration, trust, integrity, right, job, wealth, and even as far as friendship and connection between friends, family and fellow workers or employees.

Third, little things such as past records and history can also be used to attack a person's reputation. These records are considered as personal, even when internet has not yet grown into a such massive scale as today. Wyer (2012) believes that while the growth of internet makes the data collection more convenient, those records that are easily provided, can be at risk to be used as a slander, to destroy a person's or a organization's reputation. (pp.55-56). Furthermore, these records are difficult to alter or remove, especially those that are provided on the public record sites. Public record sites are often provide outdated and inaccurate ratings and records of a person. Records sites often provide detailed information such as size of a person's house, address, value of the house itself, taxes and even landscape and roads around the neighborhood. Wyer (2012) thinks that this exposures makes people feel violated be it offline or online (pg. 58). While the records are often difficult to change, it can be altered in a way that the person's record may look bad, even though the reality says differently. The way the records can be altered is through ratings. According to Wyer (2012), good ratings can be easily turned into a bad ratings in matter of seconds just because of an inaccurate, false rating that is given by a disgruntled, angry customer or even a rival. (pg. 58). These bad records can result in the decline of a person's reputation, which can lead into frustration for the victim and deficit in income if the victim is a business owner.

Image Repair Theory or also known as Image Restoration Theory is a theory introduced by William Benoit, which purpose is to outline strategies that can be used to restore damaged image or reputation to the public. Benoit is a professor of Communication Studies in University of Alabama at Birmingham who created Image Repair Theory and Functional Theory of Political Campaign (University of Alabama at Birmingham, n.d.). This theory is written on his book titled Accounts, Excuses, and Apologies: A Theory of Image Restoration Strategies. I want to use this theory to show how the victim of hoax news restore or repair the image that has been stained by the accuser.

There are two basic components that must be present during an event of an attack to a personal or organization image or reputation. First, the victim held a responsible for an certain action. Second, the act is considered as offensive for the accuser (Benoit, 1995, p.1). The first refers to when the accused was attacked, criticized, blamed, or casted suspicion on by a person or an organization. The second one refers to when the accuser believe that the act is considered offensive.

The theory of Image Repair builds on theories of apologia. Apologia is an apology, as in defense or justification of a belief, idea, etc. (Apologia, n.d.). Benoit's apologia was influenced by some others apologia theories. Some examples are Rosenfield's theory of Analog, Ware and Linkugel's theory of Apologia and Kenneth Burke's theory of Goals and Purification. The five strategies are: denial, evading responsibility, reducing offensiveness, corrective action and mortification. In this occasion, I will use the first three out of five available strategies that my main character, Boedi, will use in the story.

Denial strategy is when the accused denies all the act that occurred, or shift the blame to the accuser or even the 'real' culprit. Denial is the simplest method of image restoration because by simply denying the accusation, a person rejects the problem that are imposed to the person itself (Oklahoma University, 1997, para 6). Denial itself can be valid if the accused does not do the said act. The second form of denial is shifting the blame. Shifting the blame, also known as deflection, is a method to counter the blame to someone else. A person can directly point at a specific person, or indicating that someone has a motive (Oklahoma University, 1997, para 7).

Evading Responsibility is when the accused attempt to evade the responsibility by claiming that there are other circumstances that happened (Oklahoma University, 1997, para 8). These other circumstances can be in form of a force outside the accused power that forces the accused to do such action. There are four components in this part, but I will choose one that will appear in the story because most components will not work in my plot and will not make sense if it is used. The component that I choose is Defeasibility or Unlikely. Unlikely is when the victim shows that he or she is an unlikely culprit of an act (Oklahoma University, 1997, para 9). There are several reasons that can be given to achieve the prove the innocence such as lack of strength or skill, was on different location, or was sleeping during a certain time. 
Reducing Offensiveness is when the accused attempt to reduce the negative feeling of the society around him (Oklahoma University, 1997, para 10). There are six components, but I will only choose two out of six components because some components will not work in my plot. The components that I choose are Bolstering and Attacking Accuser. Bolstering is when the accused try to remind the society or the audience the good deeds and good reputation that the accused have done in the past (ibid). By bolstering, the accused can present a testimony from a witness that is close to the accused to confirm that the accused never did anything wrong. The second part that I would like to use is attacking the accuser. Attacking accuser is when the accused fight back by demanding the accuser to present a proof that the accused indeed did something wrong, based on the accusation (Oklahoma University, 1997, para 14). By attacking back the accuser, the accused can prove himself or herself as innocent by giving an argument that the accused is unhappy with the accusation. With a proper argument, the accused can present his or her innocence.

Lastly, I will discuss what methods that I will use in making this work. For that purpose, I will use both primary research and secondary research to work on the creative work and answer all problems that I have stated in the statement of the problem.

To obtain the necessary information and data, I will interview several people who had experience a slander or gossip in his or her life. The information or data that I will get includes the source of the slander or hoax news, how the victim feel when he/she found the slander, how their friends react to the gossip, how the victim resolve the issue and how the conclusion with the culprit if applicable.

In addition, I will use the Internet as my secondary research to obtain information and data that I cannot get in my primary research. There are several news and cases that show companies or a single person trying to restore their image to the public. For that reason, I will find the specific procedures that the companies or a person do to restore their image. In addition, I will find what kind of evidence that the companies or a person use to restore their damaged image and how they present those data to the public. This way, I can understand more and present me with much more options on how to restore a damaged image.

My informants are my friends who have told their stories of being slandered/framed in the church. One of my informants is a pastor of a church who shared his story through one of the sermon this year. As this is my source of information that will create a much more realistic story, I interview my informants through an semi-open questions where further information can be gathered depending on my informant's story circumstances.

\section{DESIGN CONCEPT}

The genre that I would like to use in the creative work is a subgenre in fiction, which is realistic fiction. The main characteristic of this genre is the character, the place, the event could actually exist and interact in real life. (Andrews, n.d.) The setting of time and place can be historical, but it can also based on real life events as well (Sweetland, n.d.). I choose this genre as it allows me to explore how a victim restore his or her image with a realistic solution. In addition, it allows me to explore how the society reacts to the victim's statement of defense.

In creating this work, I was inspired by the true story of Taufik Hidayat, the owner of meatball stand in Bekasi. Taufik sense the urgency on convincing the society that his meatball does not contain pork. The way he convince the society is by giving proof that his stand got a "Halal" symbol from Indonesian Ulema Council (MUI) that is real and cannot be replicated. He even explains his experience of going back and forth to Bandung just to get the "Halal" symbol. Despite the rejection and ignorance by the society, Taufik managed to restore his damaged image, although his business have lost more than $50 \%$ of its income (Djamhari, 2017). From the story, I want to use his sense of urgency for my main character's motivation to restore his image. My main character knows that if he fails to restore his image, he will not be able to work in anywhere else due to his damaged image. Since the genre will be realistic fiction, the story, character and place will be fictional but could happen realistically as in real life.

Another inspiration comes from the book titled "Bad News: Last Journalists in Dictatorship", written by an Indian journalist, Anjan Sundaram. I am inspired with his style of writing, where he emphasizes more on the short and rather simple description of the actions and objects in the story. The description in my story will be longer than the ones from "Bad News. For example, my story 
will have at least six sentences or more in description part, rather than just three or four sentence per description. In addition, there will be slightly more dialogues in the story to make it more realistic as possible. In "Bad News", there are only three to five very short dialogues per occasion and rarely shows character's action. In my story, character actions will be described as well as having slightly more dialogues while keeping it from 3 to 6 dialogues per occasion. Lastly, I will also use third person instead of first person point of view, which will allow me and the readers to see other character's feeling rather than just one.

\section{SYNOPSIS}

Boedi was an exceptional and influential manager in his company, PT. Malangka Industry, a dairy food processing company. His boss nominated him as one of the employees that will receive a promotion at the end of the month. However, the first hoax news about Boedi's accepting a bribery appeared in the social media. The hoax news claimed that Boedi's had accepted a bribe from a manager from PT. Pangan Megah Indonesia, a company which had a partnership with Boedi's company, to settle the deal of partnership. Since Boedi was the leading marketing employee, the other employees start to question Boedi's credibility. The hoax news not only destroyed Boedi's image but also the company's image and revenue. Boedi's boss, Ester Pratama, forced to fire Boedi from the company despite his plea. After being fired from his company, Boedi decided to apply to other food processing companies to find work. Unfortunately, all of the companies rejected his application because of Boedi's record from the hoax news. To make matter worse, the second hoax news about Boedi using his power to abuse his own employee were spread to the public. This devastated his career further to the point where he was in complete distress and despair. Overwhelmed with such destruction Boedi's mind fought to make his next choice: whether to commit suicide or leave the city to start a new life. When Boedi was preparing to leave the city, William, one of Boedi's best friends, called him. William told him that there was still a way to fight back the hoax news, in which Boedi reluctantly said yes.

To restore Boedi's damaged image and prove his innocence, Boedi followed William's suggestion, which was to present his defense against the hoax news and prove his innocence. To do all the clarifications, Boedi collected all of his past records that would help him to present his true self and deny all the claims made from the hoax news. Boedi then went to the police to file a case that he was slandered and submitted his records so the police could audit his records. The police, however, was stuck in their investigation, which made Boedi to make his own investigation based on the information that he could access at the moment.

First, Boedi tied to contact the account user that spread the hoax news. While waiting, Boedi called the number which was used to spread the hoax news through Whatsapp. To his surprise, the number didn't belong to the culprit but someone else who had received the SIM card. Boedi tracked down the person and found out that the first user of the SIM card was working on the same company as Boedi. He then turned to William and Rafi to find out the one who owned the particular number. Rafi suggested to meet up to talk more about the investigation, which Boedi accepted. They met in a restaurant not too far from the office to talk about the investigation and the progress thus far. It was revealed that Rafi held the position as a manager ever since Boedi was fired from the office. He had to go back to the office soon as he had work to do. Boedi found that Rafi had left his phone in the restaurant. As Rafi had left the restaurant, Boedi decided to brought the phone to his house instead.

Upon arriving to Rafi's house, Rafi's mom said that Boedi was a popular actor, which confuses Boedi. It was revealed that Rafi told his mom that Boedi, Rafi's ex -manager, was a poplar actor. She further said that Rafi had collected a massive amount of photos in his room, which was very suspicious for Boedi. When Boedi looked into Rafi's phone, he found the same Facebook account that was used to spread the slander. This very suspicious behavior and piece of note made Boedi sure that he culprit behind the hoax news was Rafi all along. Boedi then left Rafi's house to tell his friend and Maria about his finding.

At this time, the third hoax news emerged, saying that Boedi and Ester had a relationship together. This enraged Maria who felt that she was cheated after the years of living with Boedi. Fortunately, Boedi and Ester managed to convince Maria that it was a hoax all along. Boedi confronted Rafi in the office to stop the hoax news. It was revealed that Rafi is the one who is 
responsible for creating those hoax news that was targeted to Boedi due to his past grudge. Boedi gave Rafi two choices; either confess and stop the strike for good or Boedi will turn Rafi to the police. Rafi refused because he felt that his action was justified in the very first place. At the end, Boedi decided to turn Rafi to the police and did a press conference to the public to stabilize the situation and clear up his damaged image. In the end, Rudiaris apologized to Boedi by giving him his position back and even a promotion if Boedi wants it.

\section{CONCLUSION}

I found out that making a whole 100 pages or more novel is a lot of work, not only in the matter of number of letters and pages that I have to write, but also in the development of the story. Tackling a story about daily life may seems to be easy at first, given how my planned plot goes. However, along the way, I realized that there are many plot holes that I have to plug to make the story make more sense and not left any important details. For example, at first, I planned that there will be two press conferences, one when Boedi presented defense and two when Boedi captured the culprit. I found that making two press conferences made the story a little bit redundant as it basically repeat the same thing twice. In reality, victim of hoax news or slander only need one press conference to make the public believe to the victim more.

I also found that real world references such as news article helped me in creating the more realistic press conference. One particular article that was written is how the press conference usually goes. At first, all press conference goes as if it's an interview by media. However, at the end of the press conference, media reporters and journalists often linger around and would ask even more questions to the interviewee as their questions that they have prepared were not answered during the press conference. In addition, through the news article, I can understand how the victim presents their defense. The victim usually starts by denying the accusation made by the slander before they show their proofs. Some victims, usually politicians, can provide more than just a denial. Bank records, testimonies, and other kinds of proofs are often used to justify their defense and make their name more believable than the claims made by the hoax news.

I was rather skeptical on getting a good results through interview and thought that it was a waste of time. However, the interview results actually provide me with some interesting lesson that I can apply to the making of the creative work. One thing that I learned was that victims of slander often starts with an angry reaction rather than instantly looking for the culprit. They tend to take sometime colling off and regain their bearing and sense first before going to their investigation. The results of their investigations, however, vary between my interviewee. Some did succeed in rooting out the culprit, some others failed, and some others even don't even bother to look for a culprit. After then, they go around their friends and clear up the misunderstandings between them through denials and proofs to make the slander less believable. All of them succeed in repairing their image and some even went further to prevent such thing from happening again by keeping close contact to one another.

Lastly, I leaned about time management. It's true that I started with an advantage of 20 pages at the end of my proposal and before the project officially started. However, making the last 80 pages or more is no easy nor short time task. I have to keep up the race with time or I would ended up failing to finish the story on time. Finishing the story isn't the final step, yet. There is still conclusion and other pages that I have to deal to actually finish the whole project. I was quite lenient with my work during the early weeks of the project, mostly was because I have to make sure that my first two chapters are good and strong enough before I can proceed to make the story. Later, I found that with the time ticking closer to the end, I couldn't waste my time playing around. Fortunately, I managed to finish the story and the paper on time.

My story picks up the story at a very superficial daily life of a rather normal person. One particularly interesting thing that I can suggest is to make the character a politician, which is obviously much more higher in hierarchy than the one I have now. Politics in Indonesia is full of political maneuvers, campaign and such. Slanders and false accusations are also used to take down rivals or to even gain fame and supremacy to overpower others. This would make a much more interesting story and I am more than delighted to see if there is someone who would dare to make such story. I have to give a warning that politicians in Indonesia are very sensitive on what the media said and made. Thus, be very careful in treading the story so the politicians and the reader 
won't get mad. The theory of Image Repair Theory can also be used to analyze the ideas and possible actions that the character can do. In addition, I suggest future writers to use

One last interesting suggestion that I can give is to make the situation reversed. Instead of being slandered, the slander is instead used to gain fame and power. This unusual and possibly crazy idea would make even more interesting on how the character can keep up with their claims before their eventual fall as people realize the claim was nothing more than just a word.

\section{REFERENCES}

Andrews, N. (n.d.). What are some characteristics for the genre of realistic fiction? Retrieved from https://penandthepad.com/characteristics-genre-realisticfiction-10068941.html

Arti Berita Bohong dan Menyesatkan dalam UU ITE, (2012, January 4). HukumOnline.com. Retrieved from: http://www.hukumonline.com /klinik/detail/lt4eef8233871f5/arti-berita-bohong-dan-menyesatkan-dalam-uu- ite Apologia, (n.d.). Retrieved from https://www.merriam-webster.com/dictionary /apologia

Benoit, W. (2015). Accounts, excuses, and apologies: a theory of image restoration strategies.

Retrieved from http://www.sunypress.edu/pdf /63107.pdf

Djamhari. (2017, September 28). Kasihan! jadi korban hoax di medsos, pedagang bakso ini ditinggal pelanggan. Okezone News. Retrieved from https://news.okezone.com/read/2017/09/28/338/1784702/kasihan-jadi-korban-hoax-di-med sos-pedagang-bakso-ini-ditinggal-pelanggan

Fiction. (1998, June 23). Encyclopedia Britannica. Retrieved from https://www.britannica.com/ar/fiction-literature

Lismartini, E., \& Mukti, F. G. (2018, March 14). Jokowi: yang tuduh saya PKI akan saya gebuk. Retrieved from https://www.viva.co.id/berita/politik /1016468-jokowi-yang-tuduh-saya-pki-akan-saya-gebuk

Realistic Fiction. (n.d). Retrieved from: https://www.goodreads.com/genres /realistic-fiction Novel (1999, July 26). Encyclopedia Britannica. Retrieved from:

https://www.britannica.com/art/novel

Oklahoma University. (1997). Image repair discourse and crisis communication. Retrieved March 24, 2018, from http://www.ou.edu/deptcomm /dodjcc/groups/98A1/Benoit.htm

Purnomo, S. (2017, February 09). Disebut wanita penghibur di Alexis, Melinda: hati saya nyeri. Liputan 6. Retrieved from http://showbiz.liputan6.com/read /2851154/disebut-wanita-penghibur-di-alexis-melinda-hati-saya-nyeri

Sweetland, R. (n.d.). Realistic Fiction - Description of story elements and quality characteristics. Retrieved from http://www.homeofbob.com/literature/genre /fiction/realFictnElmnts.html

Wyre, S. (2014). Violated online: how online slander can destroy your life \& what you must do to protect yourself. Music Square East, TN: Dunham Books

University of Alabama at Birmingham. (n.d.). William L Benoit. Retrieved December 20，2017, from http://www.uab.edu/cas/communication

/faculty-directory/william-l-benoit 